\title{
Pengaruh Besaran Akrual, Ukuran Perushaan, Volatilitas Arus Kas, Dan Volatilitas Penjualanterhadap Presistensi Laba \\ (Studi Empiris Perusahaan Sektor Property, Real Estate and Building Contruction di Bursa Efek Indonesia Tahun 2017-2019)
}

\author{
Dyta Febriantine Pratikto ${ }^{1}$, Mohamad Zulman Hakim², Dirvi Surya \\ Abbas $^{3}$ \\ Universitas Muhammadiyah Tangerang ${ }^{1,2,3}$ \\ email korespondensi: dytafebriantine@gmail.com
}

\begin{abstract}
Abstrak: Penelitian ini bertujuan untuk menguji dan menemukan bukti empiris mengenai pengaruh volatilitas arus kas, volatilitas penjualan, besaran akrual dan ukuran perusahaan pada perusahaan sektor Property, Real Estate and Building Contruction terhadap persistensi laba. Sampel yang digunakan dalam penelitian ini adalah perusahaan yang terdaftar di Bursa Efek Indonesia (BEI) selama periode 2017-2019. Total sampel adalah 39 perusahaan. Data dikumpulkan dengan menggunakan metode purposive sampling. Analisis penelitian ini menggunakan regresi berganda dengan program EViews 9.0. Hasil penelitian ini menunjukkan bahwa Volatilitas Arus Kas mempengaruhi Persistensi Laba sedangkan Volatilitas Penjualan, Ukuran Perusahaan dan Besaran Akrual tidak mempengaruhi Persistensi Laba.
\end{abstract}

Kata Kunci: Persistensi Laba, Besaran Akrual, Ukuran Perusahaan, Volatilitas Arus Kas, Volatilitas Penjualan

Persistensi laba menurut Wijayanti (2006) adalah koreksi dalam laba akuntansi yang diharapkan di masa mendatang (expected future earnings) yang terkait oleh laba tahun berjalan. Besarnya koreksi ini menunjukkan tingkat persistensi laba. Perubahan terhadap laba sekarang adalah pengalihan terhadap laba masa depan, yaitu manfaat masa datang yang akan diperoleh oleh pemegang saham. Bila perusahaan tiba-tiba melaporkan laba dengan tingkat kenaikan yang sangat signifikan dibandingkan tahun tahun sebelumnya maka ada kemungkinan manajemen telah merekayasa dengan menggunakan cara yang tidak benar. Sebaliknya bila perusahaan tiba - tiba melaporkan laba tingkat penurunan yang sangat drastis atau mengalami kerugian dalam jumlah besar tanpa keterangan yang memadai juga patut dicurigai karena mungkin saja manajemen berusaha untuk menghindari pajak. (Lako, 2007:52).

PT Bumi Serpong Damai Tbk (BSDE) pada akhir Desember 2018 mencatatkan laba bersih $\mathrm{Rp} 1,293$ triliun atau turun $73,71 \%$ dibanding periode yang sama tahun 2017 yang tercatat sebesar Rp4,92 triliun.Data tersebut tersaji dalam laporan keuangan perseroan periode yang berakhir tanggal 31 Desember 2018 dengan telah audit yang diunggah pada laman Bursa Efek Indonesia. Pendapatan emiten properti ini tercatat sebesar Rp6,62 triliun atau turun 35,97\% dibandingkan akhir 
Desember 2017 yang tercatat sebesar Rp10,34 triliun. Sedangkan beban langsung dan beban pokok penjualan mengalami penurunan sebesar $32 \%$ dari Rp1,87 triliun menjadi Rp2,75 triliun. Selain itu, kewajiban perseroan tercatat sebesar Rp21,81 triliun atau turun 30,2\% dibanding akhir tahun 2017 yang tercatat sebesar Rp16,75 triliun. Sementara ekuitas perseroan tercatat sebesar Rp30,28 triliun atau naik 3,73\% dibanding akhir tahun 2017 yang tercatat sebesar Rp29,19 triliun. Adapun aset perseroan tercatat sebesar Rp52,1 triliun atau naik 13,38\% dibanding akhir tahun 2017 yang tercatat sebesar Rp45,95 triliun. (https://pasardana.id/news/2019/3/28/bsde-alami-penurunan-laba-73-71-tahun2018/,2019).

Besaran akrual adalah besaran pendapatan diakui pada saat hak kesatuan usaha timbul saat penyerahan barang ke pihak luar dan biaya diakui pada saat kewajiban timbul lantaran penggunaan sumber ekonomik yang melekat pada barang yang diserahkan tersebut ( Amaliyah dan suwarti,2017). Penelitian menurut (Amaliyah dan suwarti,2017) besaran akrual berpengaruh positif signifikan terhadap persistensi laba. Sedangkan menurut (Dewi Sa'adah,dkk, 2017) Besaran akrual berpengaruh signifikan negatif terhadap persistensi laba. Dan menurut (Linawati,2016) Besaran akrual tidak berpengaruh terhadap Persistensi Laba.

Volatilitas arus kas yang tinggi akan menyebabkan persistensi laba yang rendah, karena informasi arus kas saat ini sulit untuk memprediksi arus kas di masa mendatang. Menurut Firmansyah (2006) volatilitas sering disamakan dengan risiko. Semakin tinggi volatilitas maka akan semakin berisiko menimbulkan ketidakpastian situasi laba perusahaan di masa yang akan datang.Volatilitas aliran kas mengindikasikan adanya ketidakpastian tinggi dalam lingkungan operasi ditunjukkan oleh volatilitas arus kas yang tinggi. Jika arus kas berfluktuasi tajam maka persistensi laba akan semakin rendah. Menurut (Lailatul Lutfiyah,2016) Volatilitas arus kas berpengaruh positif signifikan terhadap persistensi laba. Dan menurut (Susilo dan Anggraeni,2016) Volatilitas arus kas berpengaruh signifikan negatif terhadap persistensi laba dan Menurut (Salma Nur Fauziyah,2019) Volatilitas arus kas tidak berpengaruh signifikan terhadap persistensi laba.

Volatilitas Penjualan adalah bagian terpenting dari siklus operasi perusahaan dalam menghasilkan laba. Menurut (Fanani,2010) Volatilitas penjualan tidak berpengaruh signifikan terhadap persistensi laba. Sedangkan menurut (Lailatul Lutfiyah,2016) Volatilitas penjualan berpengaruh signifikan terhadap persistensi laba. Dan Menurut (Saptiani \& Fakhroni,2020) Volatilitas penjualan berpengaruh signifikan negatif terhadap persistensi laba.

Ukuran perusahaan merupakan nilai yang menunjukkan besar kecilnya perusahaan (Taures, 2011). Semakin besar instrumen tersebut, semakin besar pula ukuran perusahaan. Menurut (Susilo dan Anggraeni,2016) Ukuran Perusahaan berpengaruh positif terhadap 
Persistensi Laba, Sedangkan menurut (Hidayat dan Fauziyah,2019) Ukuran Perusahaan tidak berpengaruh terhadap persistensi laba. dan menurut penelitian (Nuraeni,dkk,2018) Ukuran perusahaan berpengaruh negatif terhadap persistensi laba.

\section{METODE}

Penelitian ini menggunakan pendekatan kuantitatif dengan bentuk asosiatif. Penelitian ini dilakukan untuk mengetahui pengaruh besaran akrual, ukuran perusahaan, volatilitas arus kas, dan volatilitas penjualan terhadap persistensi laba. Penelitian ini dilakukan pada sektor Property, Real Estate and Building Contruction yang terdaftar di Bursa Efek Indonesia (BEI).

Metode yang digunakan dalam penelitian ini adalah purposive sampling dimana peneliti menentukan pengambilan sample dengan kriteria khusus yang sesuai dengan tujuan penelitian. 1). Perusahaan terdaftar di BEl tahun 2017-2019. 2). Perusahaan Property, Real Estate and Building Contruction yang tidak konsisten mempublish laporan keuangannya periode 2017- 2019. 3). Perusahaan Property, Real Estate and Building Contruction yang menggunakan mata uang asing periode 2017-2019. 4). Perusahaan Property, Real Estate and Building Contruction yang mengalami kerugian periode 2017-2019.

Dalam penelitian ini, teknik analisis data yang digunakan adalah analisis regresi data panel dengan bantuan software pengolah data statistic yaitu Eviews 9.0. berikut adalah metode analisis data yang digunakan:

1. Analisis Statistik Deskriptif Statistik deskriptif digunakan untuk memberikan gambaran untuk mendeskripsikan suatu data variabel yang dilihat dari nilai mean, nilai maksimum, minimum, dan standar deviasi dari satu variabel dependen dan tiga variabel independen.

2. Estimasi Regresi Data Panel Menurut Sriyana (dalam Eksandy, 2018:21-26), model regresi data panel terbagi menjadi 3, yaitu:

a. Common Effects Model (CEM)

b. Fixed Effect Model (FEM)

c. Random Effect Model (REM)

3. Teknik Pemilihan Model Regresi Data Panel Teknik pemilihan model regresi data panel terbagi menjadi 3, yaitu:

a. Uji Chow

Hipotesis dalam Uji Chow:

HO : Model mengikuti Common Effect Model (CEM)

$\mathrm{Ha}$ : Model mengikuti Fixed Effect Model (FEM)

b. Uji Hausman

Hipotesis dalam Uji Hausman:

HO : Model mengikuti Random Effect Model (REM)

$\mathrm{Ha}$ : Model mengikuti Fixed Effect Model (FEM)

c. Uji Langrage Multiplier

Hipotesis dalam Uji Langrage Multiplier adalah: 
$\mathrm{HO}$ : Model mengikuti Common Effect Model (CEM)

$\mathrm{Ha}$ : Model mengikuti Random Effect Model (REM)

4. Uji Asumsi Klasik

Diperlukan Uji Asumsi Klasik apabila model regresi yang digunakan dalam bentuk Common Effects Model atau Fixed Effects Model. Sebaliknya apabila persamaan regresi lebih cocok menggunakan Random Effects Model maka tidak perlu dilakukan uji asumsi klasik. . Uji Asumsi Klasik terdiri dari uji Linieritas, Autokorelasi, Multikolineritas, Normalitas,dan Heteroskedastisitas.Walaupun demikian tidak semua uji dilakukan dalam regresi data panel, hanya uji Multikolineritas dan Heteroskedastisitas saja yang diperlukan.

5. Uji Hipotesis

a. Uji F

Uji $\mathrm{F}$ digunakan untuk menjelaskan apakah variabel bebas mempunyai pengaruh terhadap variabel terikat, apabila uji $\mathrm{F}$ tidak berpengaruh maka penelitian tidak dapat dilanjutkan karena model penelitian tidak dapat menjelaskan adanya hubungan antar variabel.

Perbandingan $\mathrm{F}$ statistic dengan $\mathrm{F}$ tabel

$\mathrm{HO}$ : Jika F-statistic < F tabel

$\mathrm{Ha}$ : Jika F-statistic $>\mathrm{F}$ tabel

Berdasarkan Probabilitas

$\mathrm{HO}$ : Jika nilai Prob (F-statistic) $>\alpha 0,05$

$\mathrm{Ha}$ : Jika nilai Prob (F-statistic) $<\alpha 0,05$

b. Uji Koefisien Determinasi Nilai $R$ - squared berada diantara 0 sampai 1 dengan penjelasan yaitu: 1). Nilai $R$-squared harus berkisar antara 0 sampai 1. 2). Jika nilai $R$-squared sama dengan 1 , berarti naik atau turunnya variabel terikat $(Y)$ 100\% dipengaruhi oleh variabel bebas $(X)$. 3). Jika nilai $\mathrm{R}$-squared sama dengan 0 berarti, tidak ada hubungan sama sekali antara variabel independen terhadap variabel dependen.

c. Uji T

Uji t menjelaskan pengaruh variabel bebas secara parsial terhadap variabel terikat. Hipotesis dalam uji t adalah sebagai berikut:

Berdasarkan perbandingan t-statistic dengan t-tabel:

Ho: Jika nilai $t-$ statistic < t table

Ha: Jika nilai $t-$ statistic $>$ t tabel

Berdasarkan probabilitas:

Ho: Jika nilai Prob $>0,05$

Ha: Jika nilai Prob $<0,05$

6. Analisis Regresi Data Panel

Menurut (Eksandy, 2018:45), analisis Regresi Data Panel merupakan gabungan antara data cross section dan data time series, dimana unit cross section yang sama diukur pada waktu yang berbeda. Maka dengan kata lain, data panel merupakan data dari beberapa individu (sampel) yang diamati dalam beberapa periode waktu tertentu. Persamaan Regresi Data Panel adalah sebagai berikut: 
$Y_{\text {it }}=\beta_{0}+\beta_{1} X_{1 i t}+\beta_{2} X_{2 i t}+\beta_{3} X_{3 i t}+\varepsilon_{i t}$

Dimana :

$Y=$ Variabel Dependen

$\beta 0=$ Konstanta

$\beta 1,2,3=$ Koefisien Regresi Variabel Independen

$\mathrm{X} 1,2,3=$ Variabel Independen

$\mathrm{i}=$ Perusahaan

$\mathrm{t}=$ Waktu

$\varepsilon=$ Residual / Error

HASIL

Analisis Statistik Deskriptif

Tabel1. Analisis Statistik Deskriptif

\begin{tabular}{|l|c|c|c|c|c|}
\hline & PL & VAK & VP & SIZE & BA \\
\hline Mean & 0.003704 & 0.022098 & 0.311476 & 12.83108 & 0.030456 \\
\hline Median & 0.002300 & 0.016400 & 0.221100 & 12.87340 & 0.015700 \\
\hline Maximum & 0.358100 & 0.258400 & 1.712000 & 14.09480 & 0.595400 \\
\hline Minimum & -0.204800 & -0.327900 & 0.011600 & 11.15580 & -0.143700 \\
\hline Std. Dev. & 0.054699 & 0.076163 & 0.300133 & 0.620374 & 0.082705 \\
\hline Skewness & 2.098130 & -0.930999 & 1.958936 & -0.374180 & 3.508626 \\
\hline Kurtosis & 20.81746 & 8.562441 & 7.094908 & 2.813842 & 22.36423 \\
\hline & & & & & \\
\hline Jarque-Bera & 1633.468 & 167.7380 & 156.5752 & 2.899145 & 2068.048 \\
\hline Probability & 0.000000 & 0.000000 & 0.000000 & 0.234671 & 0.000000 \\
\hline & & & & & \\
\hline Sum & 0.433400 & 2.585500 & 36.44270 & 1501.237 & 3.563400 \\
\hline Sum Sq. Dev. & 0.347069 & 0.672886 & 10.44923 & 44.64420 & 0.793457 \\
\hline & & & & & \\
\hline Observations & 117 & 117 & 117 & 117 & 117 \\
\hline
\end{tabular}

Source: Eviews 9.0,2020

Pada tabel di atas, dapat dijelaskan bahwa jumlah data (observations) yang digunakan dalam penelitian ini sebanyak 117 data.

Nilai Mean terbesar dialami oleh variabel sebesar SIZE 12.83108, sementara variabel $\mathrm{PL}$ memiliki nilai mean terkecil yaitu sebesar 0.003704 .

Nilai Median terbesar dialami oleh variabel SIZE yaitu sebesar 12.87340, sementara variabel PL memiliki median terkecil yaitu sebesaar 0.002300 .

Nilai Maximum terbesar dialami oleh variabel SIZE yaitu sebesar 14.09480, sementara variabel VAK memiliki maximum terkecil yaitu sebesar 0.258400 .

Nilai Minimum terbesar dialami oleh variabel SIZE yaitu sebesar 11.15580 , sementara variabel BA memiliki minimum terkecil yaitu sebesar -0.143700 .

Nilai standar deviasi terbesar dialami oleh variabel SIZE yaitu sebesar 0.620374 , sementara variabel PL mempunyai nilai standar deviasi yang paling rendah yaitu sebesar 0.054699 . 
Positive skewness menunjukkan bahwa distribusi datanya memiliki ekor panjang di sisi kanan dan negative skewness memiliki ekor panjang di kiri. Untuk variabel PL, VP, BA memiliki nilai positif, sedangkan variabel VAK dan SIZE memiliki nilai negatif.

Kurtosis suatu data berdistribusi normal adalah 3. Bila kurtosis melebihi 3, maka distribusi data dikatakan leptokurtis terhadap normal. Bila kurtosis kurang dari 3, distribusi datanya datar (platykurtic) dibanding dengan data berdistribusi normal. Untuk variabel PL, VAK, VP, dan BA memiliki nilai kurtosis lebih dari 3, sementara variabel SIZE memiliki nilai kurtosis kurang dari 3.

Jarque-Bera adalah uji statistik untuk mengetahui apakah data berdistribusi normal. Uji ini mengukur perbedaan skewness dan kurtosis data dan dibandingkan dengan apabila datanya bersifat normal. Dengan $\mathrm{HO}$ pada data berdistribusi normal, uji JaqueBera didistribusi dengan X2 dengan derajat bebas (degree of freedom) sebesar 2. Probability menunjukkan kemungkinan nilai Jarque-Bera melebihi (dalam nilai absolut) nilai terobservasi di bawah hipotesis nol. Nilai probabilitas yang kecil cenderung mengarahkan pada penolakan hipotesis nol distribusi normal.

Pemilihan Model Regresi Data Panel

Tabel 2. Uji Chow

\begin{tabular}{|c|c|c|c|}
\hline Effects Test & Statistic & d.f. & Prob. \\
\hline Cross-section F & 0.644245 & $(38,74)$ & 0.9305 \\
\hline Cross-section Chi-square & 33.438799 & 38 & 0.6802 \\
\hline
\end{tabular}

Source: Eviews 9.0,2020

Berdasarkan tabel 2 , nilai Prob cross-section F dan cross-section chi-square $>(0,05)$ maka dapat disimpulkan bahwa Common Effect Model (CEM) lebih layak digunakan dibandingkan Fixed Effect Model (FEM). 
Tabel 3. Uji Hausman

\begin{tabular}{l} 
Correlated Random Effects - Hausman Test \\
Equation: EQ01 \\
Test cross-section random effects \\
\hline \hline \\
Test Summary
\end{tabular} \begin{tabular}{lllll} 
Chi-Sq. & & & \\
\hline \hline Cross-section random & Statistic & Chi-Sq.d.f. & Prob. \\
\hline \hline
\end{tabular}

Source: Eviews 9.0,2020

Berdasarkan tabel 3, nilai Prob cross-section random $>(0,05)$ maka dapat disimpulkan bahwa Random Effect Model (REM) lebih layak digunakan dibandingkan Fixed Effect Model (FEM).

Tabel 4. Uji Langrage Multiplier

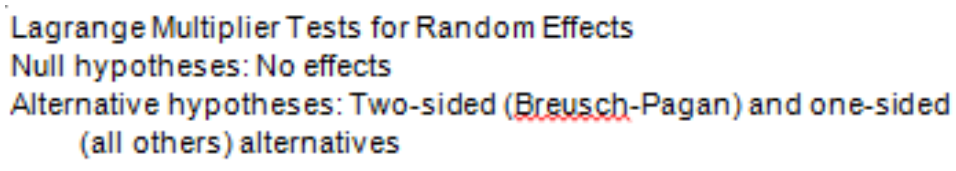

\begin{tabular}{|c|c|c|c|}
\hline & \multicolumn{3}{|c|}{ Test Hypothesis } \\
\hline & Cross-section & Time & Both \\
\hline Breusch-Pagan & $\begin{array}{l}5.439560 \\
(0.0197)\end{array}$ & $\begin{array}{l}0.955020 \\
(0.3284)\end{array}$ & $\begin{array}{l}6.394580 \\
(0.0114)\end{array}$ \\
\hline
\end{tabular}

Source: Eviews 9.0,2020

Berdasarkan tabel 4, nilai Prob cross-section breusch-pagan < $(0,05)$ maka dapat disimpulkan bahwa Random Effect Model (REM) lebih layak digunakan dibandingkan Common Effect Model (CEM).

\section{Tabel 5. Kesimpulan Model}

\begin{tabular}{clll}
\hline No & Metode & Pengujian & Hasil \\
\hline $\mathbf{1}$ & Uji Chow & CEM vs FEM & CEM \\
\hline $\mathbf{2}$ & Uji Hausman & REM vs FEM & REM \\
\hline $\mathbf{3}$ & $\begin{array}{l}\text { Uji Langrage } \\
\text { Multiplier }\end{array}$ & CEM vs REM & REM \\
\hline
\end{tabular}

Berdasarkan hasil ke tiga pengujian yang sudah dilakukan maka dapat disimpulkan bahwa Model Regresi Data Panel yang akan digunakan dalam Uji Hipotesis dan Persamaan Regresi Data Panel adalah model Random Effect Model (REM).

Uji Hipotesis

Tabel 6. Random Effect Model

Dependent Variable: PL

Method: Panel EGLS (Cross-section random effects)

Date: 01/13/21 Time: 08:47

Sample: 20172019

Periods included: 3 
Cross-sections included: 39

Total panel (balanced) observations: 117

Swamy and Arora estimator of component variances

\begin{tabular}{|c|c|c|c|c|}
\hline Variable & Coefficient & Std. Error & t-Statistic & Prob. \\
\hline C & 0.174506 & 0.110225 & 1.583176 & 0.1162 \\
\hline $\mathrm{BA}$ & -0.183389 & 0.093881 & -1.953415 & 0.0533 \\
\hline VAK & -0.212172 & 0.102456 & -2.070854 & 0.0407 \\
\hline SIZE & -0.012441 & 0.008568 & -1.451989 & 0.1493 \\
\hline VP & -0.002878 & 0.018575 & -0.154916 & 0.8772 \\
\hline \multicolumn{5}{|c|}{ Effects Specification } \\
\hline & & & S.D. & Rho \\
\hline Cross-section random & & & 0.000000 & 0.0000 \\
\hline Idiosyncratic random & & & 0.057185 & 1.0000 \\
\hline \multicolumn{5}{|c|}{ Weighted Statistics } \\
\hline R-squared & 0.072111 & \multirow{5}{*}{\multicolumn{2}{|c|}{$\begin{array}{l}\text { Mean dependent var } \\
\text { S.D. dependent var } \\
\text { Sum squared resid } \\
\text { Durbin-Watson stat }\end{array}$}} & 0.003704 \\
\hline Adjusted R-squared & 0.038972 & & & 0.054699 \\
\hline S.E. of regression & 0.053623 & & & 0.322042 \\
\hline F-statistic & 2.176016 & & & 2.665255 \\
\hline Prob(F-statistic) & 0.076218 & & & \\
\hline \multicolumn{5}{|c|}{ Unweighted Statistics } \\
\hline R-squared & 0.072111 & \multirow{2}{*}{\multicolumn{2}{|c|}{$\begin{array}{l}\text { Mean dependent var } \\
\text { Durbin-Watson stat }\end{array}$}} & 0.003704 \\
\hline Sum squared resid & 0.322042 & & & 2.665255 \\
\hline
\end{tabular}

Source: Eviews 9.0,2020

Berdasarkan hasil table 6 , menunjukkan bahwa nilai $F$-statistic sebesar 2.176016, sementara $F$ Tabel dengan tingkat $\alpha=5 \%$, df1 $(k-1)=$ 5 dan df2 $(n-k)=26$ didapat nilai $F$ Tabel sebesar 2.455831. Dengan demikian F-statistic (2.176016) < F Tabel (2.455831) dan nilai Prob(Fstatistic) $0.076218>0,05$ maka dapat disimpulkan bahwa $\mathrm{Ha}$ diterima, yang artinya variabel - variabel independen dalam penelitian ini yang terdiri dari Besaran Akrual, Ukuran Perusahaan, Volatilitas Arus Kas, dan Volatilitas Penjualan secara bersama-sama memiliki pengaruh terhadap Persistensi Laba.

Berdasarkan hasil table 6, menunjukkan Berdasarkan tabel di atas, menunjukkan bahwa nilai Adjusted R-squared sebesar 0.038972, artinya bahwa variasi perubahan naik turunnya Persistensi Laba dapat dijelaskan oleh Besaran Akrual, Ukuran Perusahaan, Volatilitas Arus Kas, dan Volatilitas Penjualan sebesar 3,89 persen, sementara sisanya yaitu sebesar 96,11 persen dijelaskan oleh variabel - variabel lain yang tidak diteliti dalam penelitian ini.

Nilai $t$-statistic Volatilitas Arus Kas (VAK) sebesar -2.070854, sementara $t$ Tabel dengan tingkat $\alpha=5 \%$, df $(n-k)=34$ didapat nilai $t$ Tabel sebesar 2.022691. Dengan demikian $t$-statistic VAK $(-2.070854)>\mathrm{t}$ Tabel (2.055529) dan nilai Prob $0.0407<0,05$ maka dapat disimpulkan 
bahwa variabel Volatilitas Arus Kas dalam penelitian ini memiliki pengaruh terhadap Persistensi Laba

Nilai $t$-statistic Volatilitas Penjualan (VP) sebesar -0.154916, sementara $\mathrm{t}$ Tabel dengan tingkat $\alpha=5 \%$, df $(n-k)=34$ didapat nilai $\mathrm{t}$ Tabel sebesar 2.022691. Dengan demikian $t$-statistic VP $(-0.154916)<\mathrm{t}$ Tabel (2.022691) dan nilai Prob. $0.8772>0.05$ maka dapat disimpulkan bahwa variabel Volatilitas Penjualan dalam penelitian ini tidak memiliki pengaruh terhadap Persistensi Laba.

Nilai $t$-statistic Ukuran Perusahaan sebesar -1.451989 , sementara t Tabel dengan tingkat $\alpha=5 \%$, df $(n-k)=34$ didapat nilai $t$ Tabel sebesar 2.022691. Dengan demikian $t$-statistic Ukuran Perusahaan $(-1.451989)<\mathrm{t}$ Tabel (2.022691) dan nilai Prob. $0.1493>0.05$ maka dapat disimpulkan bahwa variabel Ukuran Perusahaan dalam penelitian ini tidak memiliki pengaruh terhadap Persistensi Laba.

Nilai $t$-statistic Besaran Akrual (BA) sebesar -1.953415, sementara t Tabel dengan tingkat $\alpha=5 \%$, df $(n-k)=34$ didapat nilai t Tabel sebesar 2.022691. Dengan demikian $t$-statistic Besaran Akrual (BA) $(-1.953415)<\mathrm{t}$ Tabel (2.022691) dan nilai Prob. $0.0533>0.05$ maka dapat disimpulkan bahwa variabel Besaran Akrual (BA) dalam penelitian ini tidak memiliki pengaruh terhadap Persistensi Laba.

Persamaan Model Regresi Data Panel

$\mathrm{Y}=0.174506-0.212172 \mathrm{VAK}-0.002878 \mathrm{VP}-0.012441 \mathrm{SIZE}-0.183389 \mathrm{BA}+\varepsilon$

Persamaan regresi diatas memiliki makna sebagai berikut:

Nilai konstanta $=0.174506$ bernilai positif. Hal ini mengindikasikan Persistensi Laba sebesar 0.174506 dengan ketentuan variabel dalam penelitian ini tidak dimasukkan dalam persamaan regresi atau bernilai konstan 0 (nol). Nilai koefisien regresi variabel Volatilitas Arus Kas (VAK) negatif sebesar 0.212172. Hal ini berarti semakin besar Volatilitas Arus Kas, maka Persistensi Laba semakin rendah. Nilai koefisien regresi variabel Volatilitas Penjualan (VP) negatif sebesar 0.002878 . Hal ini berarti semakin besar Volatilitas Penjualan, maka Persistensi Laba semakin rendah. Nilai koefisien regresi variabel Ukuran Perusahaan (SIZE) negatif sebesar 0.012441. Hal ini berarti semakin besar Ukuran Perusahaan, maka Persistensi Laba semakin rendah. Nilai koefisien regresi variabel Besaran Akrual (BA) negatif sebesar 0.183389 . Hal ini berarti semakin besar Besaran Akrual, maka Persistensi Laba semakin rendah.

Interpretasi Hasil

Berdasarkan uji t (parsial) menunjukkan koefisien negative sebesar $-2,070854$ dengan tingkat signifikansi sebesar $0,00407<\alpha=0.05$. Karena tingkat signifikan lebih kecil dari $\alpha=0.05$ maka $\mathrm{H}_{1}$ diterima sehingga simpulannya adalah Volatilitas Arus Kas (VAK) berpengaruh terhadap Persistensi Laba (PL). Volatilitas arus kas yang tinggi akan menyebabkan persistensi laba yang rendah, karena informasi arus kas saat ini sulit untuk 
memprediksi arus kas di masa mendatang. Hasil penelitian ini didukung oleh (Susilo dan Anggraeni,2016) terdapat penelitian terdahulu yang menemukan hasil yang berbeda pada volatilitas arus kas operasi terhadap persistensi laba yang menjelaskan bahwa tidak terjadi korelasi yang signifikan antara volatilitas arus kas operasi dengan persistensi laba. Volatilitas arus kas berpengaruh negatif signifikan terhadap persistensi laba.

Berdasarkan uji t (parsial) menunjukkan koefisien positif sebesar 0,154916 dengan tingkat signifikansi sebesar $0,8772>\alpha=0.05$. Karena tingkat signifikan lebih besar dari $\alpha=0.05$ maka $\mathrm{H}_{2}$ ditolak sehingga simpulannya adalah Volatilitas Penjualan (VP) tidak berpengaruh terhadap Persistensi Laba (PL). Volatilitas penjualan mengindikasikan suatu volatilitas lingkungan operasi dan penyimpangan yang lebih besar aproksimasi dan estimasi, dan berkorespondensi dengan kesalahan estimasi yang lebih besar dan kualitas akrual yang rendah. Hasil penelitian ini didukung oleh Menurut (Fanani,2010) Volatilitas penjualan tidak berpengaruh signifikan terhadap persistensi laba.

Berdasarkan uji t (parsial) menunjukkan koefisien positif sebesar 1,451989 dengan tingkat signifikansi sebesar $0,1493>\alpha=0.05$. Karena tingkat signifikan lebih besar dari $\alpha=0.05$ maka $\mathrm{H}_{3}$ ditolak sehingga simpulannya adalah Ukuran Perusahaan (SIZE) tidak berpengaruh terhadap Persistensi Laba (PL). Hasil penelitian ini didukung oleh (Hidayat dan Fauziyah,2019) Ukuran Perusahaan tidak berpengaruh terhadap persistensi laba.

Berdasarkan uji $\mathrm{t}$ (parsial) menunjukkan koefisien negative 1,953415 dengan tingkat signifikansi sebesar $0,0533>\alpha=0.05$. Karena tingkat signifikan lebih besar dari $\alpha=0.05$ maka $\mathrm{H}_{4}$ ditolak sehingga simpulannya adalah Besaran Akrual (BA) tidak berpengaruh terhadap Persistensi Laba (PL). Laba akuntansi yang persisten adalah laba akuntansi yang memiliki sedikit atau tidak mengandung akrual dan dapat mencerminkan kinerja keuangan perusahaan yang sesungguhnya. Hasil penelitian ini didukung oleh (Linawati,2016) Besaran Akrual tidak bepengaruh terhadap Persistensi Laba.

Periode pengamatan dalam penelitian ini memiliki waktu yang sangat singkat, memiliki rentang waktu 3 tahun dari tahun 2017 2019Penelitian ini hanya menggunakan data populasi pada sektor Property, Real Estate and Building Contruction yang terdaftar di Bursa Efek Indonesia (BEI). Dalam pengambilan data beberapa perusahaan mengalami kerugian.

\section{KESIMPULAN}

Berdasarkan hasil analisis data dan pembahasan yang telah diuraikan, maka kesimpulan dari penelitian ini adalah sebagai berikut:

Volatilitas Arus Kas (VAK) berpengaruh negatif terhadap Persistensi Laba (PL). Hal ini berarti semakin besar Volatilitas Arus Kas 
(VAK), maka pengungkapan Persistensi Laba semakin rendah. Volatilitas Penjualan (VP) tidak berpengaruh terhadap Persistensi Laba (PL). Hal ini berarti semakin besar Volatilitas Penjualan (VP), maka pengungkapan Persistensi Laba semakin rendah. Besaran Akrual (BA) tidak berpengaruh terhadap Persistensi Laba (PL). Hal ini berarti semakin besar Besaran Akrual (BA), maka pengungkapan Persistensi Laba semakin tinggi. Ukuran Perusahaan (SIZE) tidak berpengaruh terhadap Persistensi Laba (PL). Hal ini berarti semakin besar Ukuran Perusahaan (SIZE), maka pengungkapan Persistensi Laba semakin tinggi.

Dari penelitian yang sudah dijelaskan diatas diharapkan dapat digunakan sebagai bahan informasi untuk penelitian lebih lanjut dimasa yang akan datang. Penelitian selanjutnya diharapkan memasukan variabel-variabel lain yang dapat mempengaruhi persistensi laba dan memasukan faktor-faktor yang memperkuat persistensi laba. Diharapkan agar menambah periode penelitian atau menggunakan data dari sektor lain yang digunakan sebagai objek penelitian.

\section{DAFTAR PUSTAKA}

Amaliyah.K,. dan Suwarti, T. (2017). Faktor-Faktor Penentu Persistensi Laba. Faktor Faktor Penentu PersistenLaba, 53(9), Nuraeni, R., Mulyati, S., \& Putri, T. E. (2018

Astutiningtyas, P. D., \& Wuryani, E. (2019). Pengaruh Volatilitas Arus Kas dan Kepemilikan Manajerial Terhadap Persistensi Laba. Jurnal Akuntansi Unesa, 7(3).

Gusnita, Y., \& Taqwa, S. (2019). Pengaruh Keandalan Akrual, Tingkat Utang dan Ukuran Perusahaan Terhadap Persistensi Laba (Studi Empiris pada Perusahaan Sektor Keuangan Yang Terdaftar di Bursa Efek Indonesia Tahun 2014-2017).

Hidayat.I., \& Fauziyah,S. (2019).Pengaruh Book Tax Differences, Arus Kas Operasi, Tingkat Hutang Dan Ukuran Perusahaan Terhadap Persistensi Laba. Journal Of Chemical Information And Modeling

Linawati. (2015). PENGARUH TINGKAT HUTANG, ARUS KAS DAN AKRUAL TERHADAP PERSISTENSI LABA DENGAN CORPORATE GOVERNANCE SEBAGAI VARIABEL MODERATING. 2005.

Rahmadhani, A. (2016). Pengaruh Book-tax Differences, Volatilitas Arus Kas, Volatilitas Penjualan, Besaran Akrual, dan Tingkat Utang terhadap Persistensi Laba (Studi Empiris pada Perusahaan Aneka Industri yang Terdaftar di Bei Tahun 2010-2014). Jurnal Online Mahasiswa Fakultas Ekonomi Universitas Riau

Shenjaya, S. (2015). Pengaruh Kinerja Corporate Social Responsibility Terhadap Persistensi Laba Pada Perusahaan Yang Bergerak Di Sektor Barang Konsumsi Dengan Rumah Tangga yang terdaftar di Bursa Efek Indonesia pada tahun 2010-2014.

Susilo, T. P., \& Anggraeni, B. M. (2015). Analisis Pengaruh Volatilitas Arus Kas, Tingkat Utang, Siklus Operasi dan Ukuran Perusahaan 
Terhadap Persistensi Laba. Jurnal Universitas Bakrie.

https://www.idx.co.id/

https://adhi.co.id/\#0

https://www.ciputradevelopment.com/en/

https://www.dpn.co.id/ 